\title{
Treatment of chronic hepatitis $C$ in a Canadian Aboriginal population: Results from the PRAIRIE study
}

\author{
Gerald Yosel Minuk MD'1 , Meaghan O'Brien MD MHSA ${ }^{1}$, Kim Hawkins RN¹, Didi Emokpare MD², \\ James McHattie $\mathrm{MD}^{2}$, Paul Harris $\mathrm{MD}^{2}$, Lawrence Worobetz $\mathrm{MD}^{2}$, Karen Doucette MD MSc${ }^{3}$, Kelly Kaita $\mathrm{MD}^{1}$, \\ Stephen Wong MD BSc MHSc${ }^{1}$, Gilles Pinette $\mathrm{MD}^{1}$, Julia Uhanova MD PhD ${ }^{1}$
}

\begin{abstract}
GY Minuk, M O’Brien, K Hawkins, et al. Treatment of chronic hepatitis $\mathrm{C}$ in a Canadian Aboriginal population: Results from the PRAIRIE study. Can J Gastroenterol 2013;27(12):707-710.
\end{abstract}

BACKGROUND: The Aboriginal population of Canada is at increased risk of exposure to the hepatitis $\mathrm{C}$ virus (HCV). Previous data indicate that spontaneous clearance of $\mathrm{HCV}$ occurs more often in Aboriginals than Caucasians. Whether this enhanced response extends to antiviral therapy for chronic HCV remains to be determined.

OBJECTIVES: To document and compare the biochemical and virological responses to antiviral therapy in $\mathrm{HCV}$-infected Canadian Aboriginals and Caucasians.

METHODS: A total of 101 treatment-naive adult patients (46 Aboriginal, 55 Caucasian) with chronic HCV genotype 1 infections were prospectively treated with pegylated-interferon and ribavirin and followed as per national guidelines.

RESULTS: Aboriginals had higher HCV-RNA loads at baseline $\left(6.42 \log _{10}\right.$ versus $\left.5.98 \log _{10} ; \mathrm{P}<0.03\right)$. Although normalization of serum aminotransferase levels, decreases in viral loads, and rapid, early and end-of-treatment virological responses were similar in the two cohorts, sustained virological responses were significantly lower in Aboriginals ( $35 \%$ versus $55 \% ; \mathrm{P}=0.047$ ). Premature discontinuation of treatment and/or loss of patients to follow-up was common (Aboriginals 37\%, Caucasians 27\%). Treatment-related side effects were similar in the two cohorts.

CONCLUSION: Despite higher rates of spontaneous HCV clearance, the response to antiviral therapy was similar, if not lower, in Aboriginals compared with Caucasians with chronic HCV genotype 1 infections. Compliance with treatment is an issue that needs to be addressed in the management of these patients.

Key Words: Aboriginal; Hepatitis; Hepatitis C; Ethnicity; First Nations; Interferon; Liver

ccording to recent national census data, there are 1.14 million A Aboriginal peoples (largely First Nations and Métis) living in Canada, with $>80 \%$ residing in Ontario, British Columbia, Alberta, Manitoba and Saskatchewan (1). Perhaps due to over-representation in high-risk populations, such as injection drug users, incarcerated persons and street-connected youth, the prevalence of hepatitis C virus ( $\mathrm{HCV}$ ) infection among Aboriginals is estimated to be four times higher than that of the general population (2).

Previous data from our group and others revealed that Aboriginal peoples have higher rates of spontaneous HCV clearance than Caucasians (3-6). This enhanced clearance is associated with heightened innate immunity as reflected by increased killer cell immunoglobulin receptor activity and muted anti-inflammatory interleukin-10 expression following exposure to $\mathrm{HCV}$ proteins (7).

Whether the higher rates of spontaneous HCV clearance in Aboriginals extend to higher rates of response to antiviral treatment remains to be determined. Thus, in the present study, we prospectively

\section{Le traitement de l'hépatite $\mathrm{C}$ chronique dans une population autochtone canadienne : les résultats de l'étude PRAIRIE}

HISTORIQUE : La population autochtone du Canada présente un risque plus élevé d'exposition au virus de l'hépatite C (VHC). Selon des données antérieures, la clairance spontanée du VHC est plus fréquente chez les Autochtones que chez les blancs. Il reste à déterminer si cette réponse accrue s'applique à la thérapie antivirale du $\mathrm{VHC}$ chronique. OBJECTIFS : Étayer et comparer les réponses biochimiques et virologiques à l'antivirothérapie d'Autochtones et de blancs du Canada infectés par le VHC.

MÉTHODOLOGIE : Au total, 101 patients adultes naïfs au traitement (46 Autochtones, 55 blancs) atteints d'une infection par le VHC chronique de génotype 1 ont subi un traitement prospectif à l'interféron pégylé et à la ribavirine, conformément aux lignes directrices nationales.

RÉSULTATS : Les Autochtones présentaient une charge de VHCARN plus élevée en début d'étude $\left(6,42 \log _{10}\right.$ par rapport à $5,98 \log _{10}$ $\mathrm{P}<0,03)$. Même si la normalisation des taux d'aminotransférases érique diminue dans les charges virales, les réponses virologiques rapides, hâtives et en fin de traitement étaient similaires dans les deux cohortes, et les réponses virologiques soutenues étaient considérablement plus faibles chez les Autochtones (35\% par rapport à $55 \%$; $\mathrm{P}=0,047$ ). L'abandon prématuré du traitement et la perte des patients au suivi étaient des phénomènes courants (Autochtones $37 \%$, blancs $27 \%$ ). Les effets secondaires du traitement étaient similaires dans les deux cohortes.

CONCLUSION : Malgré des taux plus élevés de clairance spontanée du VHC, la réponse à l'antivirothérapie était similaire chez les Autochtones et chez les blancs atteints d'une infection par le VHC chronique de génotype 1 , sinon plus faible dans le premier groupe. L'adhésion au traitement représente un problème qu'il faudra régler dans le cadre de la prise en charge de ces patients.

documented and compared HCV responses to pegylated-interferon and ribavirin treatment in adult, treatment-naive Aboriginals and Caucasians with chronic HCV genotype 1 infections.

\section{Study population}

\section{METHODS}

HCV genotype 1-infected adult patients with no additional causes of chronic liver disease attending study sites in Winnipeg (Manitoba), Regina and Saskatoon (Saskatchewan) or Edmonton (Alberta) from September 1, 2008 to January 1, 2011, meeting Canadian Association for the Study of the Liver (CASL) guidelines for treatment of chronic $\mathrm{HCV}$ infection and with no contraindications to treatment, were invited to participate in the present observational cohort study titled the Prospective Anti-HCV trial of peg-Interferon and Ribavirin in subjects of Aboriginal and Caucasian Ethnicity (PRAIRIE) $(8,9)$. After providing informed written consent, patients were treated with pegylated-interferon-alpha $2 \mathrm{a}(180 \mu \mathrm{g} /$ week $)$ and ribavirin

${ }^{1}$ Section of Hepatology, Department of Medicine, University of Manitoba, Winnipeg, Manitoba; ${ }^{2}$ University of Saskatchewan, Saskatoon, Saskatchewan;

${ }^{3}$ University of Alberta, Edmonton, Alberta

Correspondence: Dr Gerald Yosel Minuk, University of Manitoba, John Buhler Research Centre, 715 McDermot Avenue, Winnipeg, Manitoba R3E 3P4

Telephone 204-789-3204, fax 204-789-3987, e-mail gerald.minuk@med.umanitoba.ca

Received for publication August 1, 2013. Accepted September 15, 2013 


\section{TABLE 1}

\section{Baseline characteristics of study population}

\begin{tabular}{lcc}
\hline Characteristic & $\begin{array}{c}\text { Aboriginal } \\
(\mathbf{n}=\mathbf{4 6})\end{array}$ & $\begin{array}{c}\text { Caucasian } \\
(\mathbf{n}=\mathbf{5 5})\end{array}$ \\
\hline Age, years, mean $\pm \mathrm{SD}$ (median) & $45 \pm 10(48)$ & $48 \pm 10(49)$ \\
Male sex & $38(83)$ & $42(76)$ \\
Weight, kg, mean $\pm \mathrm{SD}$ (median) & $86 \pm 14(85)$ & $83 \pm 16(81)$ \\
$\mathrm{BMI}, \mathrm{kg} / \mathrm{m}^{2}$, median (range) & $28(18-40)$ & $27(18-49)$ \\
ALT, mean \pm SD (median) & $94 \pm 59(70)$ & $101 \pm 81(60)$ \\
Total bilirubin, mean $\pm \mathrm{SD}$ (median) & $13 \pm 8(11)$ & $12 \pm 7(11)$ \\
Fatty liver on imaging & $8(17)$ & $8(15)$ \\
Cirrhosis on imaging & $4(8.7)$ & $7(13)$ \\
Liver biopsy & $14(30)$ & $24(44)$ \\
Grade 0-2 & $12(86)$ & $19(79)$ \\
Grade 3 & $2(14)$ & $5(21)$ \\
Stage 0-2 & $9(64)$ & $15(63)$ \\
Stage 3 & $4(29)$ & $4(17)$ \\
Stage 4 & $1(7.1)$ & $5(21)$ \\
log RNA, median (range) & $6.42(3.63-7.50)$ & $5.98(1.74-7.33)^{\star}$ \\
\hline
\end{tabular}

Data presented as $n(\%)$ unless otherwise indicated. ${ }^{*} P=0.03$. ALT Alanine aminotransferase; BMI Body mass index

(1000 mg/day to $1200 \mathrm{mg} /$ day) and followed as per CASL guidelines. Definitions for rapid virological response, early virological response (EVR), end-of-treatment response (ETR), sustained virological response (SVR), null response, breakthroughs, relapses and futility of treatment were also as per CASL guidelines $(8,9)$.

The study was approved by the appropriate Ethics Committees of the Universities of Manitoba (Winnipeg, Manitoba), Saskatchewan (Saskatoon, Saskatchewan) and Alberta (Edmonton, Alberta).

\section{Laboratory testing}

All hematology and biochemistry testing was performed by accredited hospital laboratories at each site. Because of interlaboratory differences in the ranges of normal values, results were standardized to ratios above the upper limits of normal where appropriate.

HCV serology (anti-HCV) and HCV-RNA qualitative and quantification testing were performed using ELISAs (Amplicor and Taqman Version 1, Roche Diagnostics, Canada), respectively, at each participating centre's respective provincial laboratory. The lower limit of viral detection for the Amplicor assay is $20 \mathrm{IU} / \mathrm{mL}$ and quantification by the Taqman version 1 is $25 \mathrm{IU} / \mathrm{mL}$.

In cases in which liver histology from within one year of treatment was available, biopsy slides were reviewed and reported (METAVIR classification system) by the local pathologist for each centre.

\section{Statistics}

Statistical analysis was performed using SAS statistical software (SAS Institute Inc, USA). Categorical variables were evaluated using $\chi^{2}$ analysis. The $\chi^{2}$ test of association (or $F$ test when warranted) was used to examine differences in demographic factors, clinical variables and treatment parameters. Continuous variables were assessed using the Student's $t$ test or ANOVA. To compare the dynamic of changes in viral load and biochemical markers between the two groups, a repeated-measures ANOVA was used. Multivariate regression analysis was used to assess whether and how patients' various demographic, clinical and viral characteristics influenced outcome variables such as rates of biochemical and virological response. Decreases in viral load and quantitative assessments (frequency) of parameters such as the number of discontinuations, withdrawals, side effects, responses, etc, were examined using Poisson regression. Logistic regression models for predicting SVR after treatment were constructed on the basis of demographic and clinical data found to be significant on univariate analysis. All data were analyzed on an intention-to-treat basis; 95\% CIs were computed and statistical significance was set at $\mathrm{P}<0.05$.

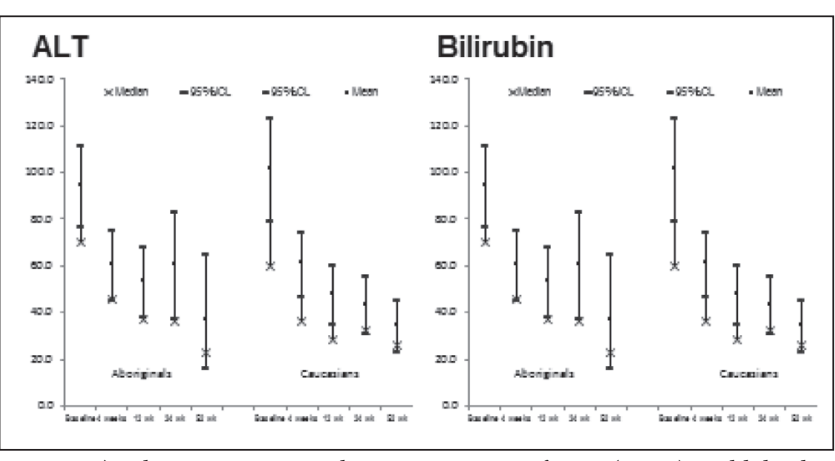

Figure 1) Changes in serum alanine aminotransferase (ALT) and bilirubin levels in Canadian Aboriginals and Caucasians being treated with pegylatedinterferon and ribavirin for chronic hepatitis $\mathrm{C}$ virus infections. The differences between the cohorts were not statistically significant. wk Week

\section{RESULTS}

A total of 122 patients enrolled in the study. Eight individuals chose not to participate after having signed the consent form but before receiving treatment. An additional 13 were excluded due to a protocol violation (enrollment of HCV genotypes 2 or 3 ). Thus, the results provided are derived from a total of 101 patients: 46 Aboriginal (37 First Nations and nine Métis) and 55 Caucasian.

The site with the largest number of patients enrolled was Regina $(n=64)$, followed by Winnipeg $(n=28)$, Saskatoon $(n=6)$ and Edmonton $(n=3)$.

Baseline characteristics of the two study cohorts (Aboriginal and Caucasian) are provided in Table 1 . The mean age, sex, weight, body mass index, alanine aminotransferase (ALT) and total bilirubin levels were similar in the two groups. The percentage of patients with radiological evidence of fatty infiltration of the liver was also similar $(17 \%$ Aboriginal and 15\% Caucasian). Although radiological evidence of cirrhosis (irregular liver margins and/or signs of portal hypertension) was more common in Caucasians ( $13 \%$ versus $8.7 \%)$, this difference did not reach statistical significance $(\mathrm{P}=0.74)$.

Of the 38 individuals (14 Aboriginal and 24 Caucasian) who had undergone a liver biopsy within one year before treatment, there were no significant differences in METAVIR grades or stages, although as with radiological imaging, a trend toward more advanced disease (stage 4) was apparent in Caucasians (21\% versus $7.1 \% ; \mathrm{P}=0.51)$.

HCV-RNA quantitation at baseline revealed that Aboriginal patients had significantly higher median HCV-RNA viral loads than Caucasians $\left(6.42 \log _{10}\right.$ versus $\left.5.98 \log _{10} ; \mathrm{P}=0.03\right)$.

The results of serum ALT and bilirubin testing over the course of treatment are provided in Figure 1. In both cases, the decrease in values was similar in the two cohorts. The percent of Aboriginals who achieved normal ALT values at four, 12, 24 and 48 weeks were $43 \%$, $50 \%, 37 \%$ and $24 \%$, respectively, compared with $51 \%, 50 \%, 45 \%$ and $38 \%$, respectively, in Caucasians. These differences were not statistically significant.

The results of HCV-RNA quantitation testing are provided in Figure 2. The mean decline in viral load from baseline to week 12 was 3.4 logs in Aboriginals and 3.0 logs in Caucasians ( $\mathrm{P}=0.48)$. HCV-RNA negative results were obtained in eight (17\%), 27 (59\%), 26 (57\%) and 25 (54\%) of Aboriginals at four, 12, 24 and 48 weeks respectively. The results at the same time intervals in Caucasians were 14 (25\%), 33 (60\%), $35(64 \%)$ and $39(71 \%)$, respectively. Once again, these differences were not statistically significant.

According to intention-to-treat analyses, eight (17\%) Aboriginals and $14(25 \%)$ Caucasians achieved rapid virological response, $31(67 \%)$ and $43(78 \%)$ EVR, $23(50 \%)$ and $36(65 \%)$ ETR and $16(35 \%)$ and 30 (55\%) SVR, respectively (Table 2). Only the difference in SVR rates achieved statistical significance $(\mathrm{P}=0.047)$.

Treatment was discontinued in 17 (37\%) Aboriginals and 15 (27\%) Caucasians $(\mathrm{P}=0.30)$. Reasons for discontinuation of treatment are provided in Table 3. The most common reason in both cohorts was 


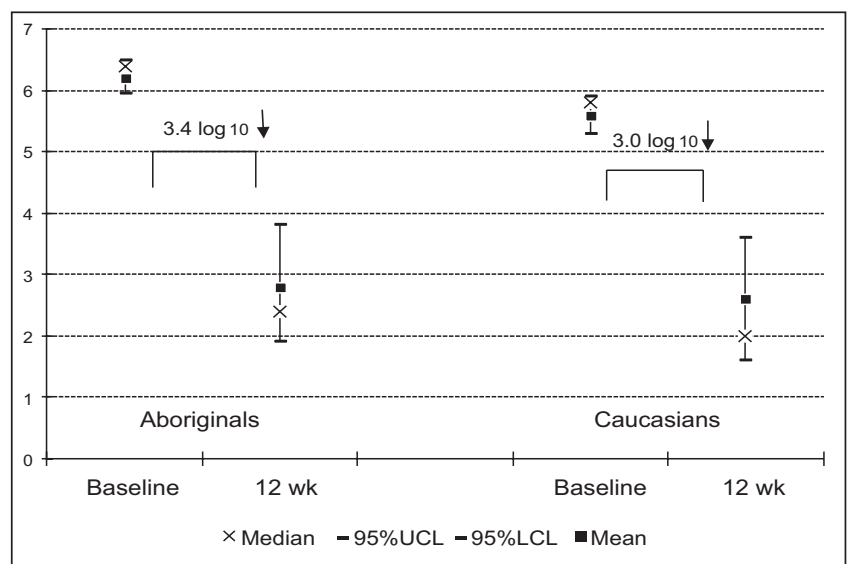

Figure 2) Declines in hepatitis $\mathrm{C}$ (HCV) viral loads in Canadian Aboriginals and Caucasians after 12 weeks (wk) of treatment with pegylated-interferon and ribavirin for chronic HCV infections. The differences between the cohorts were not statistically significant

\section{TABLE 2}

Virological outcomes of the PRAIRIE study: Intention-totreat analyses

\begin{tabular}{lcc}
\hline Outcome & $\begin{array}{c}\text { Aboriginal } \\
(\mathbf{n = 4 6 )}\end{array}$ & $\begin{array}{c}\text { Caucasian } \\
(\mathbf{n = 5 5 )}\end{array}$ \\
\hline Rapid virological reponse & $8(17)$ & $14(25)$ \\
Early virological response & $31(67)$ & $43(78)$ \\
Early treatment response & $23(50)$ & $36(64)$ \\
Sustained virological response & $16(35)$ & $30(55)^{\star}$ \\
\hline
\end{tabular}

Data presented as $n$ (\%). ${ }^{*} P=0.047$. PRAIRIE Prospective Anti-HCV trial of peg-Interferon and Ribavirin in subjects of Aboriginal and Caucasian Ethnicity

noncompliance $(20 \%$ of Aboriginals and $11 \%$ of Caucasians; $\mathrm{P}=0.22$ ).

The number and nature of serious adverse events and side effects (Table 4) were similar in the two populations and consistent with those described previously for this treatment regimen.

The results of logistic regression testing are shown in Table 5. Although Aboriginal ethnicity was associated with treatment outcome on univariate analyses, only premature treatment termination, normal baseline ALT values and the presence of fatty liver on ultrasound were associated with treatment outcome following multivariate analyses.

\section{DISCUSSION}

Based on previous epidemiological and in vitro findings, we predicted a higher response rate to antiviral therapy in Canadian Aboriginals infected with HCV compared with Caucasians. However, the results of the present study suggest that response rates are similar, if not lower, in Aboriginals. There are a number of possible explanations for this finding. First, the in vitro findings referred to above reflect differences in the innate immune response to $\mathrm{HCV}$, whereas adaptive immunity is believed to be more relevant for individuals who have progressed to and are being treated for chronic HCV infection (10). Second, baseline HCV viral loads of Aboriginals were higher than that of Caucasians, and higher viral loads are associated with lower antiviral response rates $(11,12)$. Third, although not statistically significant, the higher rate of noncompliance among Aboriginals (twice that of Caucasians) would likely have contributed to the subsequent lower SVRs in that cohort (13). Finally, the limited number of study subjects introduces the possibility of a type 2 statistical error.

Unfortunately, there are no previous publications of prospective studies describing response rates to antiviral therapy in HCV-infected Aboriginals (relative to Caucasians) that could be used for comparative purposes. The only previous report that addressed this issue was a
TABLE 3

Reasons for discontinuation of treatment in the PRAIRIE study

\begin{tabular}{lcc}
\hline Reason for discontinuation & Aboriginal & Caucasian \\
\hline Null response & $2(4.3)$ & $4(7.3)$ \\
Futility & $2(4.3)$ & $1(1.8)$ \\
Breakthrough & $1(2.2)$ & $1(1.8)$ \\
Serious adverse events & $2(4.3)$ & $3(5.4)$ \\
Nonrelated medical & $1(2.2)$ & - \\
Noncompliance & $9(20)$ & $6(11)$ \\
Total & $17(37)$ & $15(27)$ \\
\hline
\end{tabular}

Data presented as $n$ (\%). PRAIRIE Prospective Anti-HCV trial of peg-Interferon and Ribavirin in subjects of Aboriginal and Caucasian Ethnicity

TABLE 4

Side effects of treatment in the PRAIRIE study

\begin{tabular}{lcc}
\hline Characteristic & $\begin{array}{c}\text { Aboriginal } \\
(\mathbf{n}=46)\end{array}$ & $\begin{array}{c}\text { Caucasian } \\
(\mathbf{n}=55)\end{array}$ \\
\hline Dropouts due to serious adverse events & $2(4.3)$ & $2(3.6)$ \\
Suicidal & $1(2.2)$ & - \\
Idiopathic thrombocytopenic purpura & $1(2.2)$ & - \\
Decompensation (ascites) & - & $1(1.8)$ \\
Retinopathy & - & $1(1.8)$ \\
Major side effects & $19(41)$ & $21(38)$ \\
Anemia & $10(22)$ & $11(20)$ \\
Required Eprex* & $7(15)$ & $3(5.4)$ \\
Neutropenia & $1(2.2)$ & $2(3.6)$ \\
Thrombocytopenia & $1(2.2)$ & $1(1.8)$ \\
Psychiatric & $3(6.5)$ & $4(7.3)$ \\
Minor side effects & & \\
Lichen planus & - & $1(1.8)$ \\
Progressive ALT elevation & $1(2.2)$ & - \\
Weight loss & $1(2.2)$ & $1(1.8)$ \\
Weakness & - & $1(1.8)$ \\
Joint pain & - & $1(1.8)$ \\
Migraines & - & $1(1.8)$ \\
Productive cough & $1(2.2)$ & - \\
\hline Data presented & &
\end{tabular}

Data presented as $n$ (\%). *Janssen, USA. ALT Alanine aminotransferase; PRAIRIE Prospective Anti-HCV trial of peg-Interferon and Ribavirin in subjects of Aboriginal and Caucasian Ethnicity

retrospective analysis of treatment results in $\mathrm{HCV}$-infected Aboriginals and Caucasians (14). However, subjects in that report were infected with various $\mathrm{HCV}$ genotypes and unspecified numbers were treatment naive or treatment experienced. Moreover, no standardized treatment regimen or follow-up was used. Notwithstanding these limitations, the reported EVR, ETR and SVR rates were similar in that study's two cohorts.

A somewhat unexpected finding in the present study was the higher viral load documented at baseline in the Aboriginal cohort. Here again, the explanation for this finding remains unclear. Alcohol abuse can increase HCV viral loads and, although subjects with alcohol dependency were excluded from the study, intermittent alcohol abuse very likely occurred (15). Whether such abuse was more common in Aboriginal study participants, as has been described for Aboriginals in general, was not determined (16). The absence of immunosuppressive medications and negative serological testing for HIV infection (as per study exclusion criteria) render these additional causes of increased HCV viral loads unlikely.

There are a number of limitations to the present study that warrant consideration. First, the number of subjects enrolled was small. This stems from the study having been prematurely terminated due to ethical concerns resulting from the licencing of protease inhibitors that rendered pegylated-interferon and ribavirin therapy no longer the 
TABLE 5

Logistic regression analyses of variables associated with sustained virological responses

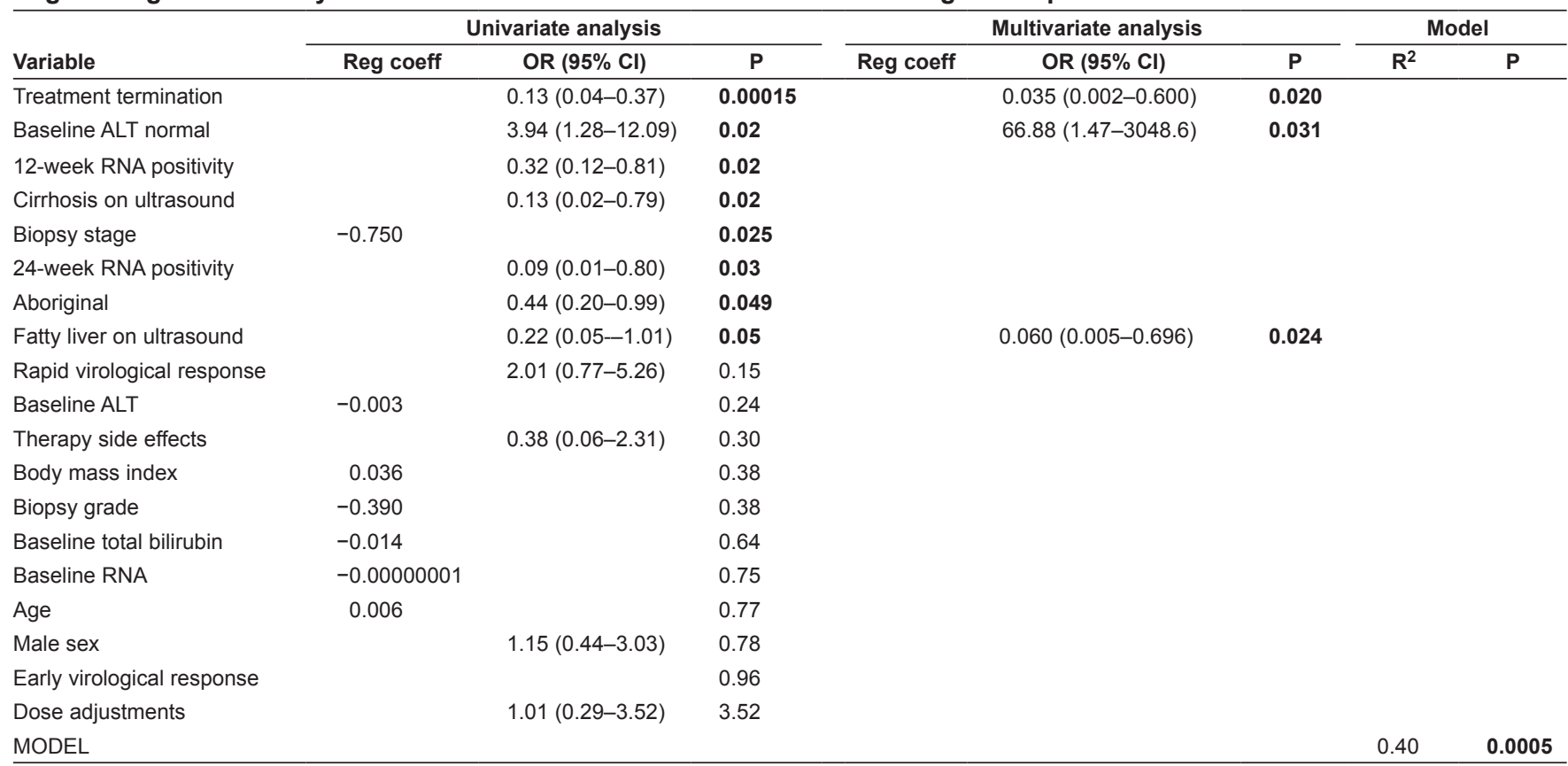

Bolded values indicate statistical significance. ALT Alanine aminotransferase; Reg coeff Regression coefficient

standard of care. Second, the limited number of liver biopsies available for analysis precluded an accurate determination of whether advanced fibrosis or cirrhosis was present and/or more common in one study cohort. Third, study investigators did not have access to interleukin-28b phenotype testing; this marker has been identified as an important predictor of response to interferon-based therapy for HCV (17). Finally, as reflected by the high noncompliance rates, resources were not available to encourage patients to continue to participate in the trial. While presumably impacting on response rates and SVRs, this limitation also provides a more 'real-world' expectation of the results of antiviral therapy in community-based populations.

\section{CONCLUSION}

The principal finding of the present study suggests that HCV genotype 1 -infected, adult Canadian Aboriginals have lower SVR rates following treatment with pegylated-interferon and ribavirin compared with Caucasians. Although the explanation for this finding remains to be determined, differences in patient compliance need to be explored.

ACKNOWLEDGEMENTS: This study was supported by a grant from Roche Canada Ltd. The authors thank the following staff for their assistance; Ms Beth McHattie, Pam Thompson, Suzanne Sumner, Sylvia Skrypnyk, Carol Dupasquier, Marianne Wiebe and Caroline Blackner. They thank Ms R Vizniak for her prompt and accurate typing of the manuscript.

\section{REFERENCES}

1. Statistics Canada. Aboriginal identity population by age groups. 2006 Census data. http://www12.statcan.ca/censusrecensement/2006/dp-pd/hlt/97-558/pages/page.cfm?Lang=E\&Geo= $\mathrm{PR} \&$ Code $=01 \&$ Table $=1 \&$ Data $=$ Count $\&$ Sex $=1 \&$ Age $=1 \&$ StartRec $=1 \&$ Sort $=5 \&$ Display $=$ Page $\&$ CSDFilter $=250$ (Accessed July, 17, 2013).

2. Remis RS. Modelling the Incidence and Prevalence of Hepatitis C Infection and its Sequelae in Canada, 2007. Final Report. HP4039/2009E-PDF;978-1-100-12614-2. < www.phac-aspc.gc.ca/sti-itssurv-epi/model/pdf/model07-eng.pdf> (Accessed August 1, 2013).

3. Minuk GY, Uhanova J. Viral hepatitis in the Canadian Inuit and First Nations populations. Can J Gastroenterol 2003;17:707-12.
4. Minuk GY, Zhang M, Wong SG, et al. Viral hepatitis in a Canadian First Nations community. Can J Gastroenterol 2003;17:593-6.

5. Grebely J, Raffa JD, Lai C, Krajden M, Conway B, Tyndall MW. Factors associated with spontaneous clearance of hepatitis $\mathrm{C}$ virus among illicit drug users. Can J Gastroenterol 2007;21:447-51.

6. Dawood M, Smart G, Wood M, Wu HX, Paton S, Wu J. Hepatitis C virus infection among First Nation and non-First Nation people in Manitoba, Canada: A public health laboratory study.

Can J Microbiol 2006;52:99-1005.

7. Rempel JD, Aborsangaya KB, Alphonse MP, Minuk GY. The influence of North American Aboriginal ethnicity on pro-inflammatory and anti-inflammatory cytokine responses to IFN-alpha. J Viral Hepat 2009;16:292-7.

8. [No authors listed]. Canadian consensus conference on the management of viral hepatitis. Canadian Association for the Study of the Liver. Can J Gastroenterol 2000;(14 Suppl B):5B-20B.

9. Myers RP, Ramji A, Bilodeau M, Wong S, Feld JJ. An update on the management of hepatitis $\mathrm{C}$ : Consensus guidelines from the Canadian Association for the Study of the Liver. Can J Gastroenterol 2012;26:359-75.

10. Spaan M, Janssen HL, Boonstra A. Immunology of hepatitis $C$ virus infections. Best Pract Res Clin Gastroenterol 2012;26:391-400.

11. Civeira MP, Prieto J. Early predictors of response to treatment in patients with chronic hepatitis C. J Hepatol 1999;(31 Suppl 1):237-43.

12. Trepo C. Genotype and viral load as prognostic indicators in the treatment of hepatitis C. J Viral Hepat 2000;7:250-7.

13. Lo Re V III, Teal V, Localio AR, Amorosa VK, Kaplan DE, Gross R. Relationship between adherence to hepatitis $\mathrm{C}$ virus therapy and virologic outcomes: A cohort study. Ann Intern Med 2011;155:353-60.

14. Cooper CL, Bailey RJ, Bain VG, et al; Canadian Pegasys Study Group. Outcomes of peginterferon alpha-2a and ribavirin hepatitis $\mathrm{C}$ therapy in Aboriginal Canadians. Can J Gastroenterol 2008;22:677-80.

15. Peters MG, Terrault NA. Alcohol use and hepatitis C. Hepatology 2002;35(5 Suppl 1):S220-5.

16. MacMillan HL, MacMillan AB, Offord DR, Dingle JL. Aboriginal health. CMAJ 1996;155:1569-78.

17. Sugiyama M, Tanaka Y, Nakanishi M, Mizokami M. Novel findings for the development of drug therapy for various liver diseases: Genetic variation in IL-28B is associated with response to the therapy for chronic hepatitis C. J Pharmacol Sci 2011;115:263-9. 


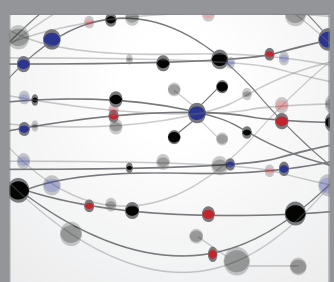

The Scientific World Journal
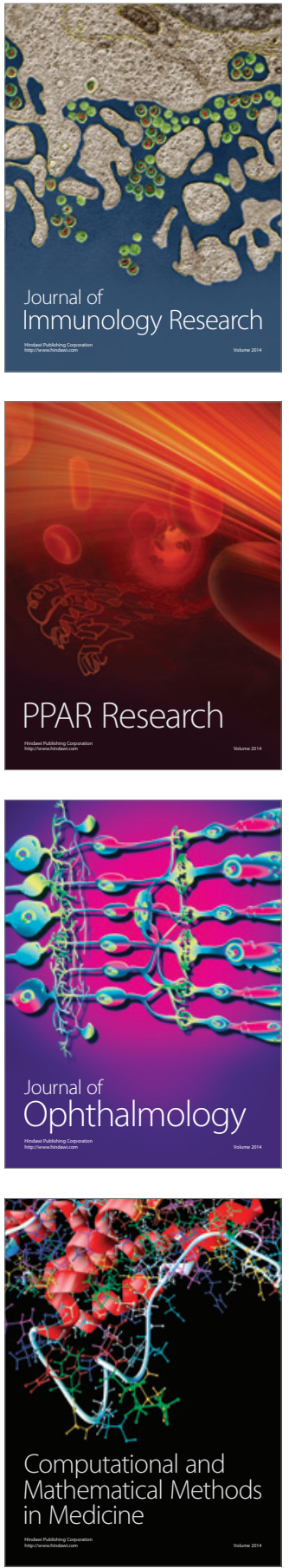

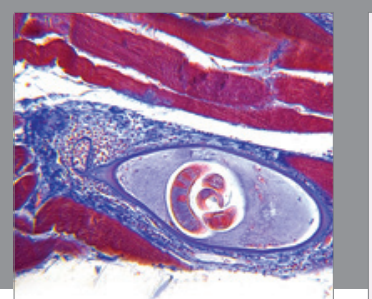

Gastroenterology Research and Practice

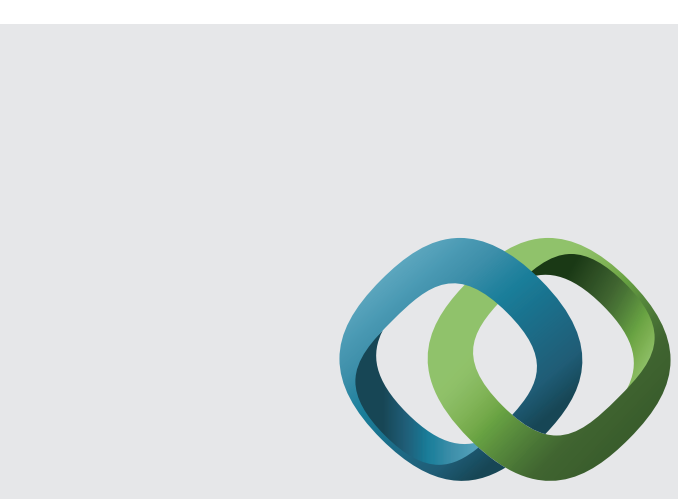

\section{Hindawi}

Submit your manuscripts at

http://www.hindawi.com
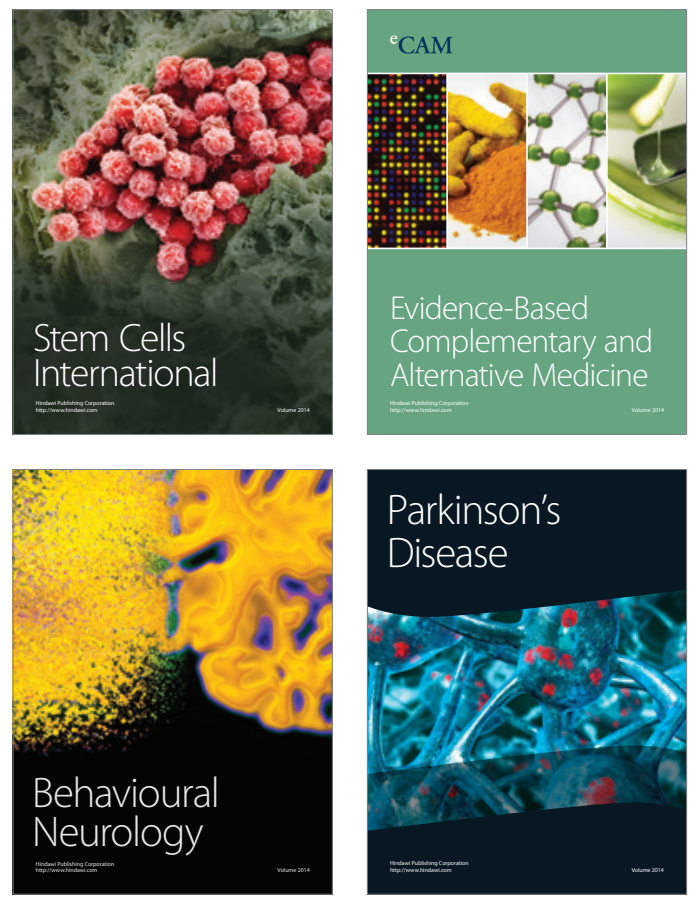
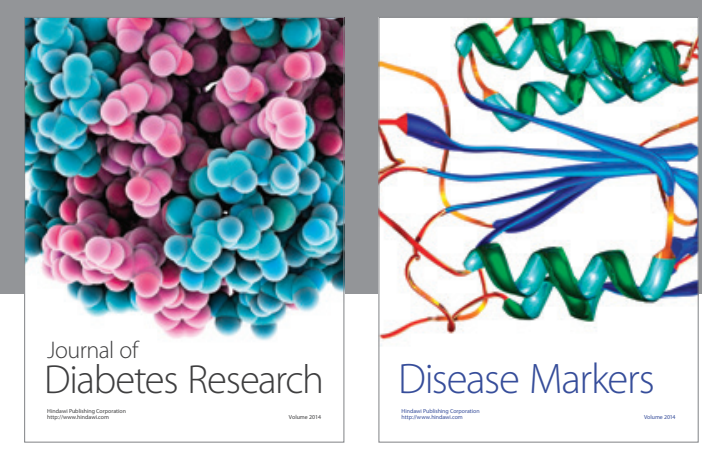

Disease Markers
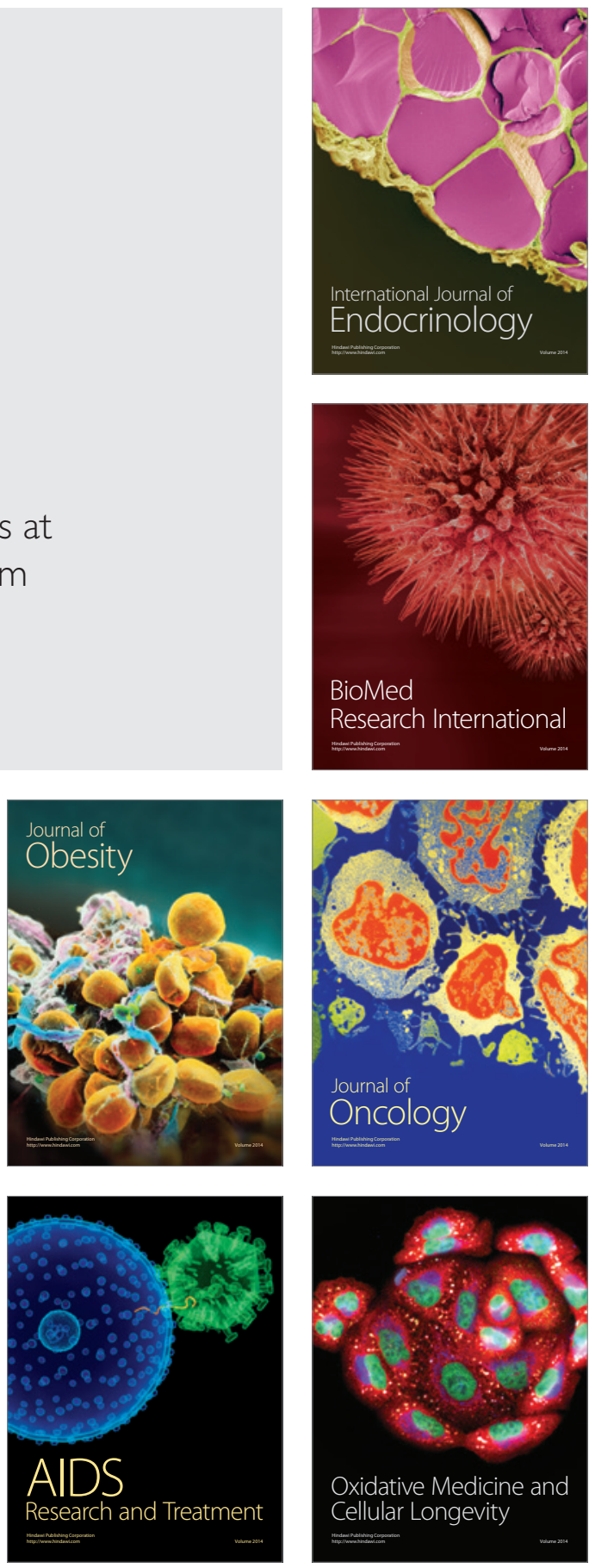